Supplement

\title{
Living Well with a Disability, a Self-Management Program
}

\author{
Craig Ravesloot, $\mathrm{PhD}^{1}$ \\ Tom Seekins, $\mathrm{PhD}^{1}$ \\ Meg Traci, $\mathrm{PhD}^{1}$ \\ Tracy Boehm, MPH ${ }^{1}$ \\ Glen White, $\mathrm{PhD}^{2}$ \\ Mary Helen Witten, MPH, MSW 3 \\ Mike Mayer ${ }^{4}$ \\ Jude Monson ${ }^{4}$ \\ ${ }^{1}$ University of Montana, Missoula, Montana \\ ${ }^{2}$ The University of Kansas, Lawrence, Kansas \\ ${ }^{3}$ Division of Human Development and Disability, National Center on Birth Defects and Developmental Disabilities, CDC, Atlanta, Georgia \\ ${ }^{4}$ Summit Independent Living Center, Missoula, Montana
}

Corresponding author: Craig Ravesloot, University of Montana. Telephone: 406-243-2992; E-mail: craig.ravesloot@mso.umt.edu.

\section{Summary}

Approximately 56.7 million persons in the United States have functional impairments that can lead to disability. As a group, persons with disabilities show disparities in measures of overall health when compared with the general population. Much of this can be attributed to secondary conditions rather than to the impairment itself. Persons with disabilities can prevent and manage many of the conditions that contribute to these disparities. The Living Well with a Disability program was developed to support persons with disabilities to manage their health. The curriculum helps participants achieve early success in self-management of quality-of-life goals to build confidence for making health behavior changes; it includes 11 chapters that facilitators use to conduct an orientation session and 10 weekly, 2-hour sessions. The program has been implemented by 279 community-based agencies in 46 states. On the basis of the data from the field trial, these community applications have served approximately 8,900 persons since 1995, resulting in an estimated savings of \$6.4-\$28.8 million for health care payers. Persons with disabilities have unique needs that can be addressed through multiple levels of intervention to reduce health disparities. The Living Well with a Disability program is a promising intervention that has demonstrated improvements in health-related quality of life and health care use.

\section{Introduction}

Approximately 56.7 million persons (18.7\%) in the United States live with one or more communicative, mental, or physical disabilities (1). Disability occurs when a person's environment does not accommodate their functional ability (2). Persons with disabilities are at higher risk for poor health (3-9). Evidence indicates that approximately half of all health care expenditures can be accounted for by the $15 \%-20 \%$ of the population who have a disability (10). However, persons with disabilities often have not been included in health promotion research or programs $(6,11,12)$. Disability advocates and those studying disability and health have demonstrated that, among other factors, improved self-management skills among persons with disabilities can lead to improved health and wellness and improved ability to advocate for structural changes, which can improve their access to quality health care in the United States (12-14).

The definition and operationalization of disability is the subject of ongoing discussion $(15,16)$, which has helped to clarify and distinguish disability status from health outcomes $(11,17,18)$. The International Classification of Functioning, Disability, and Health combines medical and social models to highlight the interaction of function and environment in the creation of disability (2). This framework for understanding disability presumes that disability and related health disparities can be improved through improved physical and social functioning (e.g., assistive technology, physical therapy, peer support, and employment) and through modifications that make the environment accessible to persons regardless of functional ability (e.g., accessible buildings, information technology, and social policy) $(19,20$ ).

A growing body of literature indicates that persons with disabilities experience significant health disparities including poorer overall health and more chronic conditions $(6,21)$, some of which have been referred to as secondary conditions $(13,22)$. Secondary conditions are health conditions that are more frequent among persons who have disabilities than among those without disabilities. Various studies have shown that persons with disabilities frequently have to manage multiple secondary conditions that might further limit activities and participation, stress health-promoting routines, and lead to acute health care episodes, including emergency care visits and hospitalizations (5,23-25). In 2010, approximately five times more persons with disability reported fair or poor health compared with persons 
without disability (39.4\% versus 8.6\%) (26). Furthermore, persons with disability reported 10.2 days of poor physical health in the past 30 days, whereas persons without disability reported 1.8 days of poor physical health (26).

Health disparities have led to a growing interest in public health interventions that can have far-reaching effects and that can make healthy behavior easier and more likely among diverse populations (27). For persons with disabilities, multiple levels of intervention are needed to address environmental, health systems, and individual behavior determinants of health (G). Many health problems experienced by persons with disabilities can be prevented and managed by health education interventions that target a person's ability to self-manage chronic disease risk and overall health status $(11,14,28)$. Significant improvements in health status following implementation of health promotion programs have been reported for persons with spinal injury (29), amputation (30), stroke (31), multiple sclerosis (32), arthritis (33), and intellectual and developmental disabilities $(34,35)$. All of these studies focused on subsets of the population with disabilities defined by a single specific medical condition; few have investigated effects among diverse populations with disabilities. To address this gap, the Living Well with a Disability program was developed in partnership with the national network of Centers for Independent Living (CILs) as a self-management program intended to support healthy living among persons with mobility impairments irrespective of their medical condition.

CDC's Office of Minority Health and Health Equity selected the intervention analysis and discussion that follows to provide an example of a program that might be effective in reducing disability-related disparities in the United States. Criteria for selecting this program are described in the Background and Rationale for this supplement (36).

\section{Methods}

\section{Intervention Methods}

Living Well with a Disability was developed to address selfmanagement needs of persons with mobility impairments. A community-based participatory research (CBPR) approach was used to shape the curriculum content based on participant input and epidemiological research (37-40). Input from this process confirmed that adults with mobility impairments experienced a wide range of secondary conditions (e.g., pain, depression, and obesity) and social conditions that limited their ability to participate in desired events and activities. These findings led to discussions on the ecological context of persons with mobility impairments to design suitable interventions. Persons in the general population can learn skills to prevent and manage chronic conditions $(41,42)$. Because strategies for effectively delivering health promotion content to persons with functional impairments were unknown, CBPR methods were used to help specify the nature of the problem more accurately and to design an inclusive intervention.

Federally funded CILs are organizations that meet criteria for having access to the target population and organizational features that make these centers capable of meeting intervention objectives $(43,44)$. CILs are nonresidential resource and advocacy centers that support the needs of persons with disabilities to help them live independently in the community. They are organized into a national network with approximately 600 offices that share 1) a common philosophy about the nature of disability consistent with the social model of disability; 2) a consistent approach to helping persons live independently that focuses on personal responsibility, choice, and control; and 3) a core set of services including information and referral provisions, peer support, independent living skill development, and personal and systems advocacy to increase the accessibility of community environments (45). Before development of the Living Well with a Disability program, health promotion was not a service commonly provided by CILs (45).

Previous research suggested that an effective self-management strategy should incorporate life skills that facilitate the development of meaningful life activities to provide a context for addressing health behavior change (46). This strategy encourages persons with disabilities to set quality-of-life goals that include health behavior changes as essential objectives.

The Living Well with a Disability curriculum is geared to helping participants achieve early success in self-management of quality-of-life goals that build confidence and motivation for making health behavior changes (47). The program includes 11 chapters that facilitators use to conduct an orientation session and 10 weekly, 2-hour sessions. The first chapter, an orientation session, addresses the recruitment and retention challenges identified by community sites (and identified in research as barriers to program participation experienced by persons with disabilities). In this session, participants explore potential obstacles to attendance (e.g., fear and anxiety when going to a venue that might not accommodate their needs, such as having an accessible restroom), examine the potential benefits of participating in the program, and consider strategies they might use to overcome barriers. The next four sessions encourage peer support through a supportive solutionfocused group process; they help participants develop hope that they can achieve a more meaningful and healthy life while addressing the early challenges of pursuing new goals. These sessions build analysis and problem-solving skills (e.g., frustration management and self-monitoring for depression to 
identify needs for clinical intervention). The last six sessions focus on specific self-management skills for improving health status, including 1) strategies for effective communication with health care providers, 2) strategies for information acquisition and use, 3) strategies for increasing activity (through six levels from sedentary to recommended levels of exercise), 4) strategies for improving diet (based on U.S. Department of Agriculture guidelines), 5) strategies for advocating for both personal and health care systems improvements, and 6) cognitive and behavioral strategies for maintaining health behavior changes over time (Table 1). Additional program information is available at www.livingandworkingwell.org.

\section{Data Collection and Analysis}

The Living Well with a Disability program has been assessed in several published studies that are summarized in this report. No new findings are presented. The program was originally evaluated in a pilot study in 1992 (46) and revised before evaluation (1998-1999) using a randomized, quasiexperimental, staggered baseline design that included a convenience sample of 246 CIL consumers from nine sites geographically distributed across eight states in the United States (California, Kansas, Mississippi, Montana, Missouri, New Hampshire, New York, and Texas) $(48,49)$. Participant demographics (e.g., mean age: 45 years; range: $18-85$ years; $82.4 \%$ white; $64.2 \%$ women) were representative of the U.S. population of persons with mobility impairments. Participants had been living with an impairment for an average of 17.5 years (standard deviation $[\mathrm{SD}]=15.7)(49)$.

Program effectiveness was evaluated by collecting data on secondary conditions (23), symptom days, life satisfaction (50), health care use as reflected by costs (e.g., primary care and emergency department visits, outpatient surgery, and hospital days), and healthy lifestyle (Table 2) (51). Data were collected 2 months prior, immediately before the intervention, immediately after the intervention, and at 2 months, 4 months, and 12 months after the intervention. Because of the staggered baseline design that requires implementation of the intervention with all participants, outcome data were analyzed by using separate between-subject (i.e., logistic regression) and within-subject procedures (i.e., repeated measures analysis of variance). The level of statistical significance for all analyses conducted was $\mathrm{p}<0.05$.

\section{Results}

Between-subject results indicated that participants in the intervention group were significantly more likely than those in the control group to be below the median for secondary conditions (adjusted odds ratio [AOR]: 3.05; 95\% confidence interval [CI]: 1.33-7.01), symptom days (AOR: 1.96; 95\% CI: 0.91-4.26) and health care use (AOR: 1.94; 95\% CI: 1.03 3.67) after adjusting for demographics and preintervention status with respect to the median of each variable (49).

The within-subject analysis indicated that observed changes in all outcome measures occurred during the intervention period and were maintained up to 12 months for secondary conditions, healthy lifestyle, and life satisfaction. Symptom days returned to baseline at 12 months, and health care costs returned to baseline at 2 months (Table 2). No change was observed over the extended baseline period (i.e., period without treatment prior to the intervention) on any of the outcomes measured, indicating that observed differences resulted from the Living Well with a Disability program rather than from instrumentation effects associated with the measurement procedures (48).

\section{Discussion}

In addition to person-level outcomes, a cost analysis of the Living Well with a Disability (Living Well) program was conducted. The cost analysis used the payer perspective, which reflects the costs incurred by health insurers and other payers (52). Self-reported health care utilization data were used to compute health care unit costs incurred by study participants at each measurement period (53). Overall, cost outcomes for the entire sample indicated a 6 -month cost savings of $\$ 3,227$. To examine outcomes for participants without high health care expenditures (i.e., more than three standard deviations above the mean), a sample trimmed to include only persons with seven or fewer hospital nights during any measurement period was also reported. The 6 -month health care cost savings for this sample was $\$ 723$. Overall, the Living Well program recovered all costs of program implementation, including in-person facilitator training and data collection (\$596 per participant), within 4 months of program delivery for both the complete and the trimmed sample populations (53).

By May 2015, the Living Well program had been implemented by 279 community-based agencies in 46 states to approximately 8,900 persons with disabilities. On the basis of the 6-month cost savings observed in the field trial (i.e., $\$ 723$ and $\$ 3,227$ ), these community applications are estimated to have saved \$6.4-\$28.8 million, which would have been incurred since February 1995 by health care payers without program implementation.

Several factors might affect dissemination of this program. Historically, health promotion has not been a mandated service in the U.S. health care system. In addition, many organizations, 
TABLE 1. Living Well with a Disability curriculum content, objectives, and rationale for intervention components

\begin{tabular}{|c|c|c|}
\hline Chapter & Primary objective & Rationale \\
\hline Orientation & $\begin{array}{l}\text { Provides introductory information about the program, so } \\
\text { persons can learn about it before committing to attend }\end{array}$ & $\begin{array}{l}\text { Persons are reluctant to commit to a class and need information } \\
\text { to make an informed choice. }\end{array}$ \\
\hline Goal setting & $\begin{array}{l}\text { Introduces the process for identifying and setting meaningful } \\
\text { quality-of-life goals; develops skills for writing goal statements }\end{array}$ & $\begin{array}{l}\text { Setting meaningful quality-of-life goals provides motivation for } \\
\text { participants to improve their health and to achieve their goals. }\end{array}$ \\
\hline Problem solving & $\begin{array}{l}\text { Teaches skills in identifying problems and generating solutions; } \\
\text { helps participants anticipate and plan for problems while } \\
\text { working toward goals }\end{array}$ & $\begin{array}{l}\text { Problem-solving skills help participants anticipate problems and } \\
\text { identify solutions in support of making progress towards goals. }\end{array}$ \\
\hline Healthy reactions & $\begin{array}{l}\text { Teaches cognitive-behavioral skills and encourages peer } \\
\text { support for dealing with frustration and setbacks as } \\
\text { participants work toward goals }\end{array}$ & $\begin{array}{l}\text { Learning to be optimistic and develop healthy reactions to } \\
\text { setbacks supports goal-directed activity. }\end{array}$ \\
\hline Beating the blues & $\begin{array}{l}\text { Provides an overview of discouragement and depression and } \\
\text { offers additional resources for seeking help with prevention } \\
\text { and management }\end{array}$ & $\begin{array}{l}\text { Depressed mood can occur as a result of frustration and } \\
\text { discouragement and disrupts goal-directed activity. }\end{array}$ \\
\hline Healthy communication & $\begin{array}{l}\text { Teaches the importance of clear communication with a focus on } \\
\text { developing skills for communicating health issues with } \\
\text { physicians and service providers }\end{array}$ & $\begin{array}{l}\text { Goal-directed activity often depends on the help and support of } \\
\text { others in the community. Communication skills promote } \\
\text { cooperation in support of goal achievement. }\end{array}$ \\
\hline Information seeking & $\begin{array}{l}\text { Provides resources for identifying needed health information, } \\
\text { evaluating the reliability of health information sources, and } \\
\text { effectively using the information once found }\end{array}$ & $\begin{array}{l}\text { Learning to find and apply reliable information specific to the } \\
\text { individual needs of the participants is an important skill for } \\
\text { improving health in support of goal achievement. }\end{array}$ \\
\hline Physical activity & $\begin{array}{l}\text { Presents information on and provides guidelines for increasing } \\
\text { healthy activity and motivates participants to make simple } \\
\text { changes to incorporate more physical activity into daily life }\end{array}$ & $\begin{array}{l}\text { Secondary health conditions can be reduced or prevented } \\
\text { through healthy physical activity. }\end{array}$ \\
\hline Eating well & $\begin{array}{l}\text { Provides information on nutrition and nutrition resources and } \\
\text { presents strategies for monitoring eating habits and } \\
\text { increasing the intake of healthy foods while limiting the intake } \\
\text { of unhealthy foods }\end{array}$ & $\begin{array}{l}\text { Secondary conditions can be reduced or prevented through } \\
\text { improvements in nutrition. }\end{array}$ \\
\hline Advocacy & $\begin{array}{l}\text { Provides information and resources for self and systems } \\
\text { advocacy and draws upon the skills learned in previous } \\
\text { chapters to support participants' advocating for and meeting } \\
\text { their needs }\end{array}$ & $\begin{array}{l}\text { Learning the steps and skills of self and systems advocacy can } \\
\text { solve problems that impede goal-directed activity (e.g., } \\
\text { problems with access to exercise facilities). }\end{array}$ \\
\hline Maintenance & $\begin{array}{l}\text { Offers information and strategies for monitoring progress } \\
\text { toward goals and maintaining health behavior changes }\end{array}$ & $\begin{array}{l}\text { Health-behavior change must be supported with strategies for } \\
\text { maintenance. }\end{array}$ \\
\hline
\end{tabular}

Sources: Adapted from Ravesloot C, Seekins T, Young Q-R. Health promotion for people with chronic illness and physical disabilities: the connection between health psychology and disability prevention. Clin Psychol Psychother 1998;5:76-85; Ravesloot C, Ruggiero C, Ipsen C, et al. Disability and health behavior change. Disabil Health J 2011;4:19-23.

such as CILs, that serve persons with mobility limitations struggle to meet their core mission across a large geographical area on small budgets. When they add a service, such as the Living Well program, they do so with limited funds. For other organizations, the functional approach adopted by the Living Well program might be unfamiliar and substantially different from the medical model of disability (2), which also might limit their ability to implement it.

The Living Well program improved the health-related quality of life and reduced health care utilization in a randomized controlled trial. Some health-status and health-related, quality-of-life improvements were still evident 12 months after the intervention. Scalability of the program is possible because it has been tested in geographically diverse parts of the United States and implemented across various organizations, including CILs, Aging and Disability Resource Centers, outpatient rehabilitation centers, and interdisciplinary wellness centers. In addition, three payers, L.A. Care Health Plan,
Inland Empire Health Plan, and the Montana 1915(c) Home and Community-Based Waiver Medicaid programs, have provided reimbursement to CILs for delivering the program. The facilitator and client workbooks are available in English, Spanish, and Korean.

The Living Well program was designed for compatibility with implementation in rural areas that often lack health promotion resources. Approximately 7.24 million noninstitutionalized persons with disabilities live in rural areas of the United States (54), and CILs have conducted Living Well trainings successfully even in remote counties and frontier counties, which have fewer than six persons per square mile. The combination of a distance training program with a workbook focused intervention has facilitated availability of the Living Well program in areas where limited resources exist for persons with disabilities.

The Living Well program has had a long history of development with funding from various sources including 
Supplement

TABLE 2. Mean scores of five outcome measures collected from participants* in the Living Well with a Disability program before, immediately after, and at 2, 4, and 12 months after intervention - eight states, ${ }^{\dagger} 2000$

\begin{tabular}{|c|c|c|c|c|c|}
\hline Measure & Pretest & Posttest & 2 months & 4 months & 12 months \\
\hline Secondary conditions ${ }^{\S}$ & 28.3 & $24.6^{\pi}$ & $24.6^{\pi}$ & $23.4^{4}$ & $24.7^{9}$ \\
\hline BRFSS symptom days** & 9.3 & $8.1^{9}$ & $7.7^{\natural}$ & $7.6^{9}$ & 8.3 \\
\hline Healthy lifestyle ${ }^{\dagger \dagger}$ & 2.4 & $2.6^{\pi}$ & $2.6^{\pi}$ & $2.6^{\pi}$ & $2.6^{\pi}$ \\
\hline Life satisfaction $\S \S$ & 2.8 & $3.0^{\pi}$ & $3.0^{\pi}$ & $3.0^{4}$ & $3.0^{\pi}$ \\
\hline Health care costs & $\$ 1,507$ & $\$ 724^{\pi}$ & $\$ 895$ & $\$ 1,306$ & $\$ 1,296$ \\
\hline
\end{tabular}

Source: Adapted from Ravesloot C, Seekins T, White G. Living well with a disability health promotion intervention: improved health status for consumers and lower costs for health care policymakers. Rehabil Psychol 2005;50:239-45.

Abbreviations: BRFSS = Behavior Risk Factor Surveillance System; HPLP II = health-promoting lifestyle profile II; HRQOL = health-related quality of life.

${ }^{*} \mathrm{~N}=126$.

† California, Kansas, Mississippi, Montana, Missouri, New Hampshire, New York, and Texas.

$\S$ Secondary conditions values are summed across 43 conditions (item range: $0-4$ ) using the Secondary Conditions Surveillance Instrument (Source: Seekins T, Smith $\mathrm{N}$, McCleary T, Clay J, Walsh J. Secondary disability prevention: involving consumers in the development of a public health surveillance instrument. J Disabil Policy Stud 1990;1[3]:21-36).

I Denotes statistically significant posthoc difference (t-test or least significant difference test) from the pretest $(p<0.05)$.

** BRFSS symptom days is the average number of days experiencing the seven symptoms included in the HRQOL-14 questionnaire (range: 0-30 days).

${ }^{++}$Healthy lifestyle is the average item score across all 52 items included in the HPLP II questionnaire (range: 0-3) (Source: Pender NJ, Walker SN, Sechrist KR, FrankStromborg M. Predicting health-promoting lifestyles in the workplace. Nurs Res 1990; 39:326-32).

$\S \S$ Single item (range: 1-4).

ๆึ Health care costs (i.e., doctor visits, emergency department visits, outpatient surgery, and hospital days) in 2000.

the CDC. In September 2015, funding was received from National Institute on Disability, Independent Living, and Rehabilitation Research to develop and evaluate a multimedia version of the Living Well program that will update delivery methods, improve fidelity of program implementation in the field, and extend programmatic reach. Additional program information is available at http://rtc.ruralinstitute.umt.edu/ health-wellness/motivation-for-self-management.

\section{Limitations}

The findings in this report are subject to at least two limitations. First, self-reported outcomes and convenience sampling can produce biases not accounted for in the experimental design. Second, the results are not generalizable beyond the population of persons with disability using CIL services.

\section{Conclusion}

Persons with disabilities have unique needs that can be addressed through multiple levels of intervention to reduce health disparities (6). CDC has responded to these needs by developing a novel effective intervention that has already realized a return on investment through its many applications at multiple sites. Because of the aging of the U.S. population, this intervention might generate greater returns as the need intensifies for interventions that address health disparities experienced by persons with disabilities.

\section{References}

1. Brault MW. Americans with disabilities: 2010, household economic studies. Washington, DC: US Department of Commerce, Economics and Statistics Administration; 2012. http://www.census.gov/prod/ 2012pubs/p70-131.pdf.

2. World Health Organization. International classification of functioning, disability, and health. Geneva, Switzerland: World Health Organization; 2001. http://www.who.int/classifications/icf/en.

3. Brandt EN, Pope AM, eds. Enabling America: assessing the role of rehabilitation science and engineering. Washington, DC: National Academy Press; 1997.

4. Wolf LA, Armour BS, Campbell VA. Racial/ethnic disparities in self-rated health status among adults with and without disabilities - United States, 2004-2006. MMWR Morb Mortal Wkly Rep 2008;57:1069-73.

5. Kinne S, Patrick DL, Doyle DL. Prevalence of secondary conditions among people with disabilities. Am J Public Health 2004;94:443-5. http://dx.doi.org/10.2105/AJPH.94.3.443.

6. Krahn GL, Walker DK, Correa-De-Araujo R. Persons with disabilities as an unrecognized health disparity population. Am J Public Health 2015;105(Suppl 2):S198-206. http://dx.doi.org/10.2105/AJPH.2014.302182.

7. US Department of Health and Human Services. Healthy people 2020. Washington, DC: US Department of Health and Human Services; 2015. http://www.healthypeople.gov/2020.

8. CDC, National Center on Birth Defects and Developmental Disabilities. Strategic plan 2011-2015. Atlanta, GA: US Department of Health and Human Services, CDC, National Center on Birth Defects and Developmental Disabilities; 2011. http://www.cdc.gov/NCBDDD/ AboutUs/documents/NCBDDD_StrategicPlan_2-10-11.pdf.

9. US Department of Health and Human Services. The Surgeon General's call to action to improve the health and wellness of persons with disabilities. Washington, DC: US Department of Health and Human Services, Office of the Surgeon General; 2005.

10. Anderson WL, Armour BS, Finkelstein EA, Wiener JM. Estimates of state-level health-care expenditures associated with disability. Public Health Rep 2010;125:44-51.

11. Drum CE, Peterson JJ, Culley C, et al. Guidelines and criteria for the implementation of community-based health promotion programs for individuals with disabilities. Am J Health Promot 2009;24:93-101, ii. http://dx.doi.org/10.4278/ajhp.090303-CIT-94. 
12. Rosen J. NCD letter to subcommittee on workforce protection regarding wellness legislation. Washington, DC: National Council on Disability; 2015. http://www.ncd.gov/publications/2015/03302015.

13. Pope AM, Tarlov AR. Disability in America: toward a national agenda for prevention. Washington, DC: National Academies Press; 1991.

14. Traci M, Seekins T. Integration of chronic disease and disability and health state programs in Montana. Disabil Health J 2014;7:19-25. http://dx.doi.org/10.1016/j.dhjo.2013.10.006.

15. Whiteneck G. Conceptual models of disability: past, present, and future [Appendix B]. In: Field MJ, Jette AM, Martin L, eds. Workshop on disability in America: a new look. Washington, DC: The National Academies Press; 2006:50-66.

16. Office of the Inspector General. The Social Security Administration's ability to prevent and detect disability fraud. Washington, DC: Social Security Administration; 2014. http://oig.ssa.gov/sites/default/files/ testimony/SSA \% 27s\%20Ability\%20to\%20Prevent $\% 20$ and $\% 20$ Detect\%20Disability\%20Fraud_0.pdf.

17. Iezzoni LI, Freedman VA. Turning the disability tide: the importance of definitions. JAMA 2008;299:332-4. http://dx.doi.org/10.1001/ jama.299.3.332.

18. Lollar DJ, Andresen EM, eds. Public health perspectives on disability: epidemiology to ethics and beyond. New York, NY: Springer; 2011. http://dx.doi.org/10.1007/978-1-4419-7341-2.

19. Rimmer JH. Use of the ICF in identifying factors that impact participation in physical activity/rehabilitation among people with disabilities. Disabil Rehabil 2006;28:1087-95. http://dx.doi. org/10.1080/09638280500493860.

20. Montirosso R, Ceppi E, D’aloisio C, Zucca C, Borgatti R. International classification of functioning, disability, and health in subjects with alternating hemiplegia of childhood. Disabil Rehabil 2009;31(Suppl 1):S10815. http://dx.doi.org/10.3109/09638280903317781.

21. Fox MH, Reichard A. Disability, health, and multiple chronic conditions among people eligible for both Medicare and Medicaid, 2005-2010. Prev Chronic Dis 2013;10:e157. http://dx.doi.org/10.5888/pcd10.130064.

22. Marge M. Health promotion for persons with disabilities: moving beyond rehabilitation. Am J Health Promot 1988;2:29-44. http://dx.doi. org/10.4278/0890-1171-2.4.29.

23. Seekins T, Smith N, McCleary T, Clay J, Walsh J. Secondary disability prevention: involving consumers in the development of a public health surveillance instrument. J Disabil Policy Stud 1990;1:21-36. http:// dx.doi.org/10.1177/104420739000100302.

24. Rasch EK, Hochberg MC, Magder L, Magaziner J, Altman BM. Health of community-dwelling adults with mobility limitations in the United States: prevalent health conditions. Part I. Arch Phys Med Rehabil 2008;89:210-8. http://dx.doi.org/10.1016/j.apmr.2007.08.146.

25. Traci MA, Seekins T, Szalda-Petree A, Ravesloot C. Assessing secondary conditions among adults with developmental disabilities: a preliminary study. Ment Retard 2002;40:119-31. http://dx.doi.org/10.1352/00476765(2002) $040<0119$ :ASCAAW >2.0.CO;2.

26. CDC. CDC health disparities and inequalities report-United States, 2013. MMWR Suppl 2013;62:(No. Suppl 3).

27. Frieden TR. A framework for public health action: the health impact pyramid. Am J Public Health 2010;100:590-5. http://dx.doi. org/10.2105/AJPH.2009.185652.

28. Rimmer JH, Vanderbom KA, Bandini LG, et al. GRAIDs: a framework for closing the gap in the availability of health promotion programs and interventions for people with disabilities. Implement Sci 2014;9:100. http://dx.doi.org/10.1186/s13012-014-0100-5.

29. Latimer AE, Ginis KAM, Arbour KP. The efficacy of an implementation intention intervention for promoting physical activity among individuals with spinal cord injury: a randomized controlled trial. Rehabil Psychol 2006;51:273-80. http://dx.doi.org/10.1037/0090-5550.51.4.273.
30. Wegener ST, Mackenzie EJ, Ephraim P, Ehde D, Williams R. Selfmanagement improves outcomes in persons with limb loss. Arch Phys Med Rehabil 2009;90:373-80. http://dx.doi.org/10.1016/j.apmr. 2008.08.222.

31. Rimmer JH, Braunschweig C, Silverman K, Riley B, Creviston T, Nicola T. Effects of a short-term health promotion intervention for a predominantly African-American group of stroke survivors. Am J Prev Med 2000;18:332-8. http://dx.doi.org/10.1016/S0749-3797(00)00129-X.

32. Bombardier CH, Cunniffe M, Wadhwani R, Gibbons LE, Blake KD, Kraft GH. The efficacy of telephone counseling for health promotion in people with multiple sclerosis: a randomized controlled trial. Arch Phys Med Rehabil 2008;89:1849-56. http://dx.doi.org/10.1016/j. apmr.2008.03.021.

33. Lorig K, Holman H. Arthritis self-management studies: a twelve-year review. Health Educ Q 1993;20:17-28. http://dx.doi.org/10.1177/ 109019819302000104.

34. McDermott S, Whitner W, Thomas-Koger M, et al. An efficacy trial of 'steps to your health', a health promotion programme for adults with intellectual disability. Health Educ J 2012;71:278-90. http://dx.doi. org/10.1177/0017896912441240.

35. Horner-Johnson W, Drum CE, Abdullah N. A randomized trial of a health promotion intervention for adults with disabilities. Disabil Health J 2011;4:254-61. http://dx.doi.org/10.1016/j.dhjo.2011.06.003.

36. Penman-Aguilar A, Boye K, Liburd L. Background and rationale. In: Strategies to reduce health disparities: selected CDC-sponsored interventions-United States, 2016. MMWR Suppl 2016;65(No. Suppl 1).

37. Seekins T, Clay J, Ravesloot C. A descriptive study of secondary conditions reported by a population of adults with physical disabilities served by three independent living centers in a rural state. J Rehabil 1994;60:47-51.

38. Whyte WF. Participatory action research. Thousand Oaks, CA: Sage Publications, Inc; 1991.

39. Seekins T, White GW. Participatory action research designs in applied disability and rehabilitation science: protecting against threats to social validity. Arch Phys Med Rehabil 2013;94(Suppl):S20-9. http://dx.doi. org/10.1016/j.apmr.2012.07.033.

40. Wallerstein NB, Duran B. Using community-based participatory research to address health disparities. Health Promot Pract 2006;7:312-23. http:// dx.doi.org/10.1177/1524839906289376.

41. Lorig KR, Mazonson PD, Holman HR. Evidence suggesting that health education for self-management in patients with chronic arthritis has sustained health benefits while reducing health care costs. Arthritis Rheum 1993;36:439-46. http://dx.doi.org/10.1002/art.1780360403.

42. Norris SL, Engelgau MM, Narayan KM. Effectiveness of selfmanagement training in type 2 diabetes: a systematic review of randomized controlled trials. Diabetes Care 2001;24:561-87. http:// dx.doi.org/10.2337/diacare.24.3.561.

43. Fawcett SB, White GW, Balcazar FE, et al. A contextual-behavioral model of empowerment: case studies involving people with physical disabilities. Am J Community Psychol 1994;22:471-96. http://dx.doi. org/10.1007/BF02506890.

44. White GW, Gutierrez RT, Seekins T. Preventing and managing secondary conditions: a proposed role for independent living centers. J Rehabil 1996;62:14-21.

45. DeJong G. Independent living: from social movement to analytic paradigm. Arch Phys Med Rehabil 1979;60:435-46.

46. Ravesloot C, Seekins T, Young Q-R. Health promotion for people with chronic illness and physical disabilities: the connection between health psychology and disability prevention. Clin Psychol Psychother 1998;5:76-85. http://dx.doi.org/10.1002/(SICI)1099-0879(199806)5: $2<76::$ AID-CPP156>3.0.CO;2-5.

47. Ravesloot C, Ruggiero C, Ipsen C, et al. Disability and health behavior change. Disabil Health J 2011;4:19-23. http://dx.doi.org/10.1016/j. dhjo.2010.05.006. 
48. Ravesloot C, Seekins T, White G. Living well with a disability health promotion intervention: improved health status for consumers and lower costs for health care policymakers. Rehabil Psychol 2005;50:239-45. http://dx.doi.org/10.1037/0090-5550.50.3.239.

49. Ravesloot CH, Seekins T, Cahill T, Lindgren S, Nary DE, White G. Health promotion for people with disabilities: development and evaluation of the Living Well with a Disability program. Health Educ Res 2007;22:522-31. http://dx.doi.org/10.1093/her/cyl114.

50. Moriarty DG, Zack MM, Kobau R. The Centers for Disease Control and Prevention's Healthy Days Measures-population tracking of perceived physical and mental health over time. Health Qual Life Outcomes 2003;1:37. http://dx.doi.org/10.1186/1477-7525-1-37.

51. Pender NJ, Walker SN, Sechrist KR, Frank-Stromborg M. Predicting health-promoting lifestyles in the workplace. Nurs Res 1990;39:326-32. http://dx.doi.org/10.1097/00006199-199011000-00002.
52. Weinstein MC, Siegel JE, Gold MR, Kamlet MS, Russell LB. Identifying and valuing outcomes [Chapter 4]. In: Gold MR, Siegel JE, Russell LB, Weinstein MC, eds. Cost-effectiveness in health and medicine. New York, NY: Oxford University Press; 1996.

53. Ipsen C, Ravesloot C, Seekins T, Seninger S. A financial cost-benefit analysis of a health promotion program for individuals with mobility impairments. J Disabil Policy Stud 2006;16:220-8. http://dx.doi.org/ $10.1177 / 10442073060160040301$

54. von Reichert C, Greiman L, Myers A; Rural Institute, University of Montana. The geography of disability in America: on rural-urban differences in impairment rates. Missoula, MT: University of Montana, Research and Training Center on Disability in Rural Communities; 2014. http://scholarworks.umt.edu/cgi/viewcontent.cgi? article $=1006 \&$ context=ruralinst_independent_living_community_participation. 